Images in...

\title{
Multiple amoebic liver abscesses
}

\author{
Safa Al-shamma, ${ }^{1}$ Sarah Rushworth, ${ }^{2}$ Bethany Sanders, ${ }^{2}$ Adrian Tang, ${ }^{2}$ Ramasamy Saravanan ${ }^{2}$ \\ 1Department of Medicine/Gastroenterology, Royal Liverpool Hospital, Liverpool, UK; \\ ${ }^{2}$ Macclesfield Hospital, Macclesfield, UK
}

Corresponding to Safa Al-shamma, safaal3@yahoo.co.uk

\section{DESCRIPTION}

A 57-year-old lady presented with a 6-day history of fever, abdominal pain, vomiting, constipation and weight loss. Her medical history included treatment with ramipril for hypertension and diverticular disease. She had been on holiday in the Dominican Republic 18 months ago and had visited Gambia a few weeks prior to admission. She had taken full malaria prophylaxis.

On examination she was pyrexial with a temperature of $40^{\circ}$ associated with a tachycardia. Abdominal examination revealed right upper quadrant tenderness. Full blood count showed a mildly elevated white cell count of $10.1 \times 10^{9} / 1$ (normal 3.6-9.2), C reactive protein was greater than $250 \mathrm{mg} / 1$ (normal $<7$ ). Amylase, urea and creatinine were all normal. Her liver function was deranged with an alkaline phosphatase of 234 IU/1 (normal 30-130), alanine transaminase of 76 IU/1 (normal 10-50), bilirubin of $25 \mu \mathrm{mol} / 1$ (normal 2-20), $\gamma$ glutamyl transferase of 276 IU/1 (normal 5-40).

The patient was started empirically on metronidazole $500 \mathrm{mg}$ intravenous three times a day. Initial liver ultrasound showed multiple well defined hypoechoic lesions suspicious of metastases, however further imaging with CT and MRI showed peripheral rim enhancement suggestive of multiple hepatic abscesses (at least six) (figures 1 and 2). Serology for immunofluorescence antibody amoebiasis was strongly positive 1 in 1024 titre. Stool cultures were negative. The patient received a total of 21 days of metronidazole and 10 days of diloxanide furoate $500 \mathrm{mg}$ three times a day to clear her luminal trophozites. The patient responded well with resolution of her abscesses without the need for aspiration or drainage(figure 3).

It is important to note that aspiration of amoebic abscesses is not required for diagnosis or treatment and is

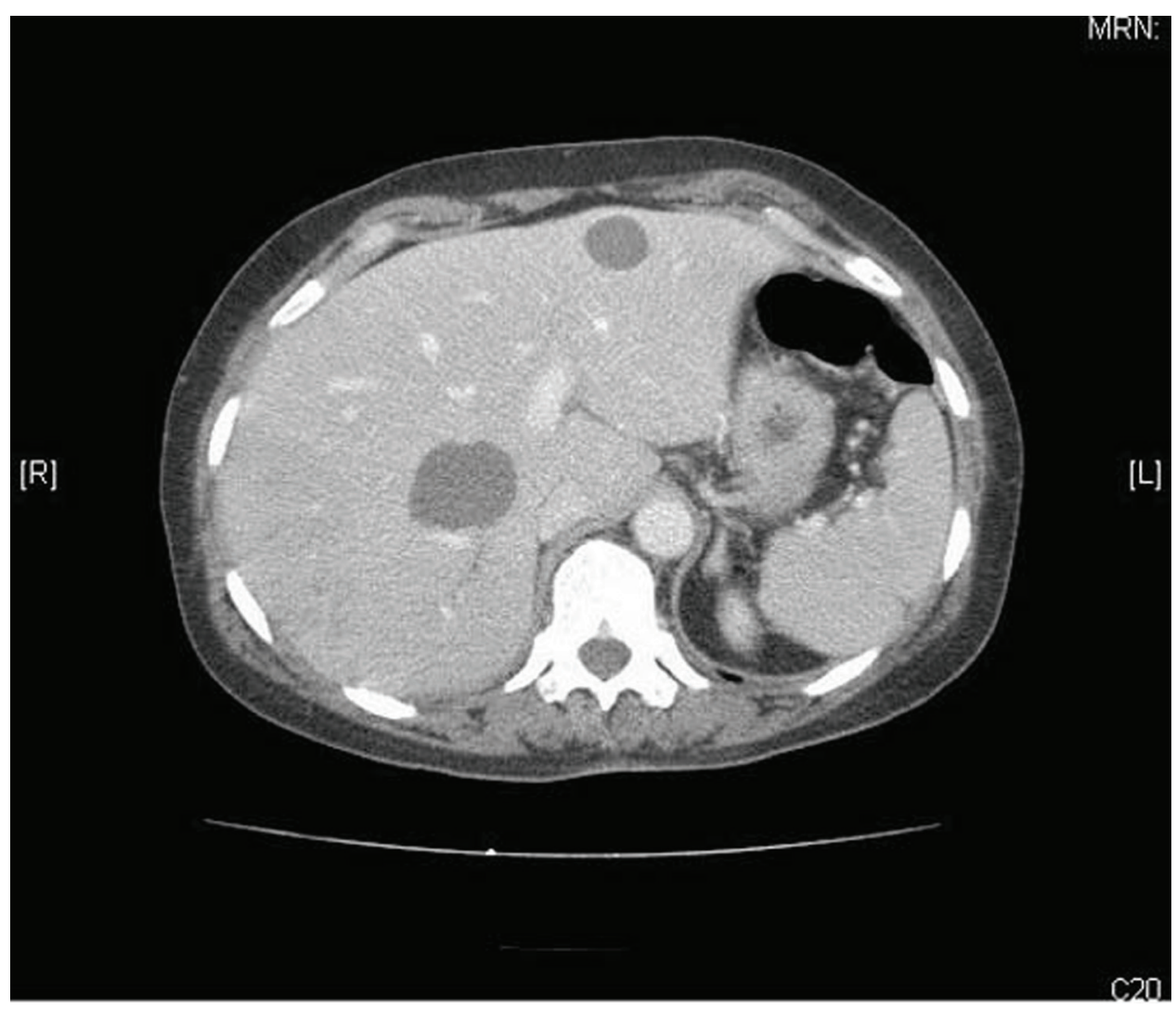

Figure 1 CT abdomen showing multiple low attenuation liver lesions with peripheral rim enhancement. 


\section{BMJ Case Reports}

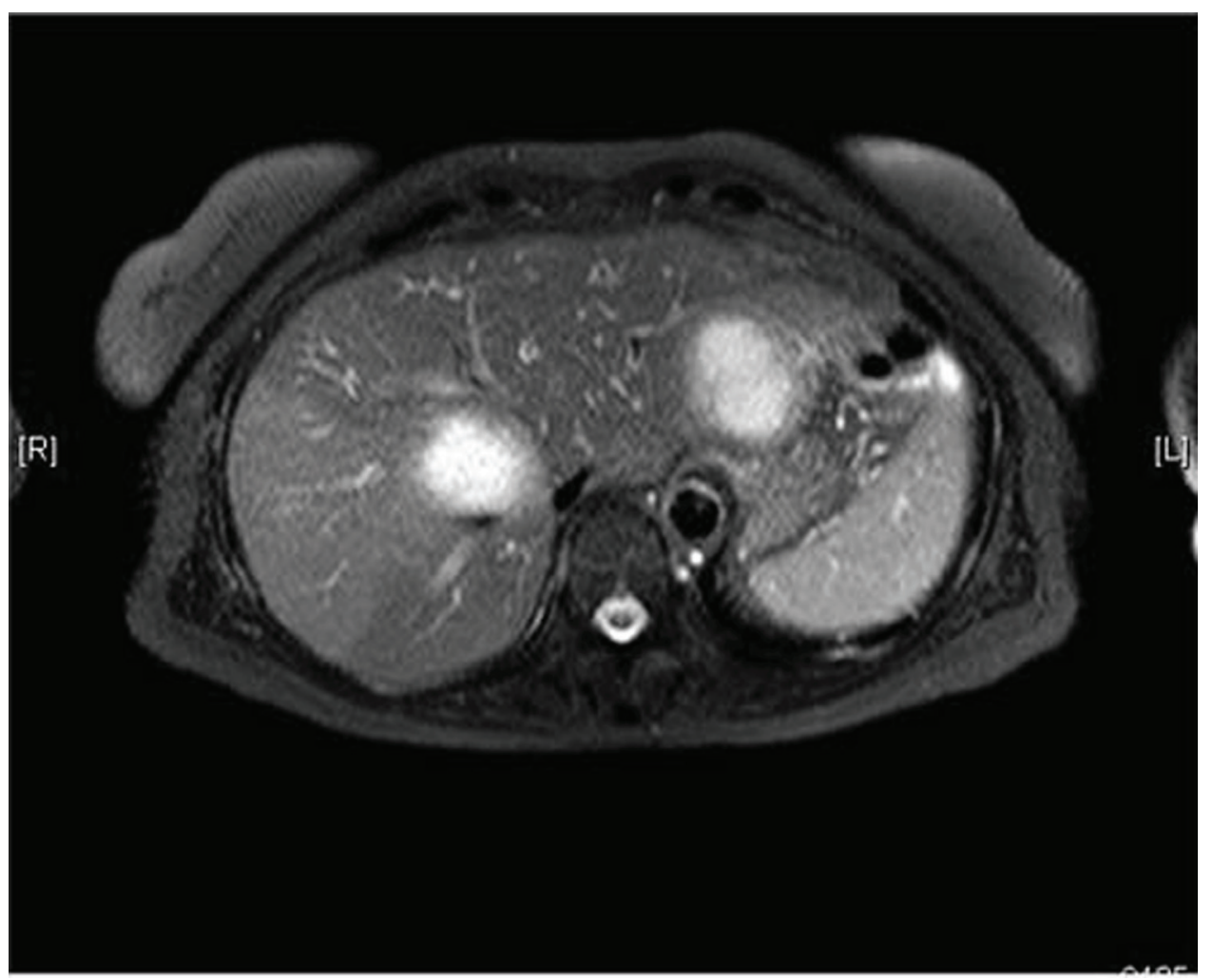

Figure 2 MRI Liver showing multiple cystic thickwalled, rim enhancing masses. The lesions return high signal on dual echo T2, consistent with multiple hepatic abscesses.

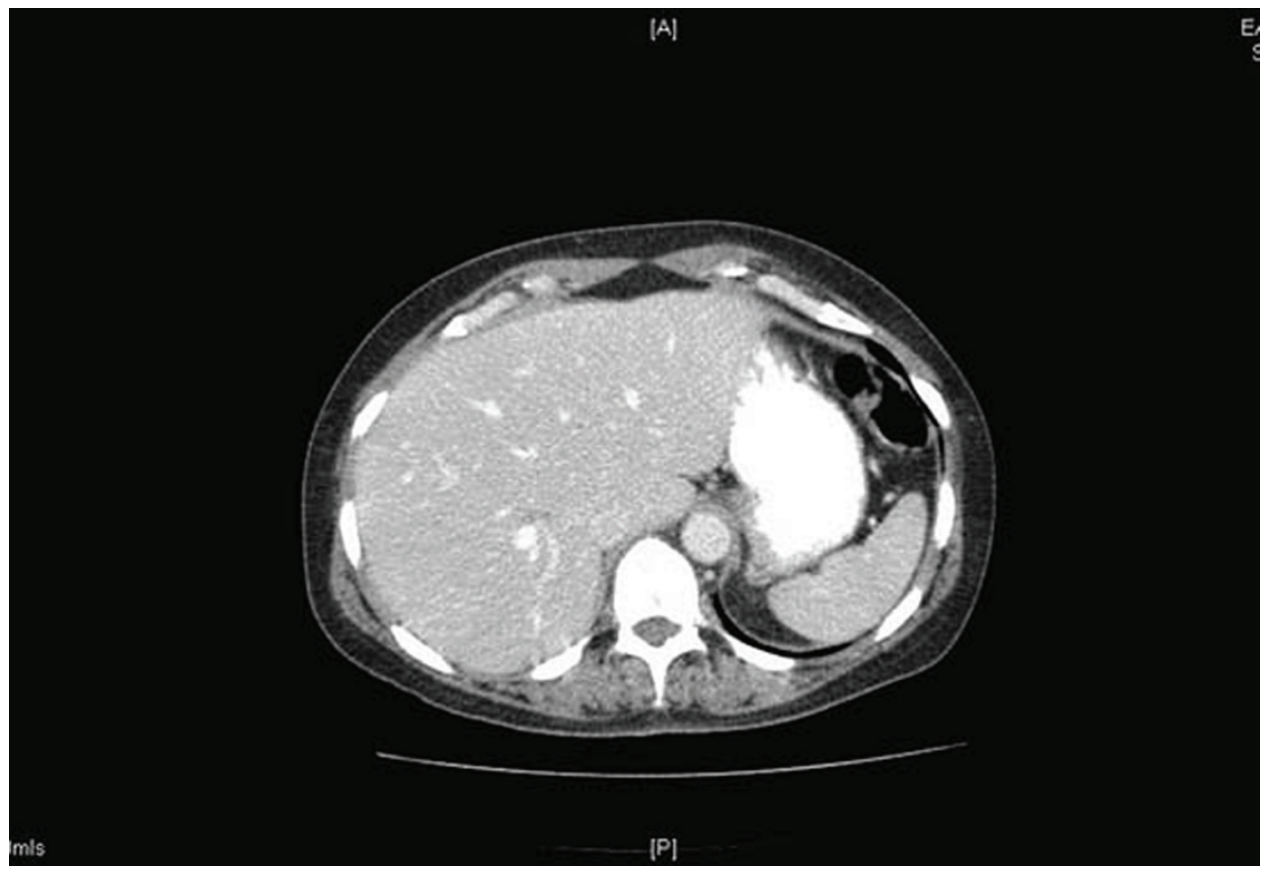

Figure 3 CT abdomen showing complete resolution of the liver lesions.

only indicated if rupture is felt to be imminent. Sensitivity of non-invasive tests such as serum and stool enzyme immunoassay or newer PCR techniques tend to offer sensitivity $>90 \%$ with excellent specificity. Serological and antigen tests normally revert to negative after successful treatment within a week. Equally, regression of the abscesses can also be expected within a week of treatment and can be further confirmation of the diagnosis.

Competing interests None.

Patient consent Obtained. 


\section{BMJ Case Reports}

This pdf has been created automatically from the final edited text and images.

Copyright 2011 BMJ Publishing Group. All rights reserved. For permission to reuse any of this content visit http://group.bmj.com/group/rights-licensing/permissions.

BMJ Case Report Fellows may re-use this article for personal use and teaching without any further permission.

Please cite this article as follows (you will need to access the article online to obtain the date of publication).

Al-shamma S, Rushworth S, Sanders B, Tang A, Saravanan R. Multiple amoebic liver abscesses. BMJ Case Reports 2011;10.1136/bcr.11.2010.3501, date of publication

Become a Fellow of BMJ Case Reports today and you can:

- Submit as many cases as you like

- Enjoy fast sympathetic peer review and rapid publication of accepted articles

- Access all the published articles

Re-use any of the published material for personal use and teaching without further permission

For information on Institutional Fellowships contact consortiasales@bmjgroup.com

Visit casereports.bmj.com for more articles like this and to become a Fellow 